\title{
Dual purpose wheat production with different levels of nitrogen topdressing
}

\section{Produção de trigo duplo propósito com diferentes doses de adubação nitrogenada em cobertura}

\author{
Éderson Luis Henz ${ }^{*}$; Paulo Sergio Gois de Almeida²; João Pedro Velho²; \\ José Laerte Nörnberg ${ }^{3}$; Leandro das Dores Ferreira da Silva ${ }^{4}$; \\ Tatiane Regina Backes ${ }^{5}$; Geisi Loures Guerra ${ }^{6}$
}

\begin{abstract}
Currently, the practice of Crop-Livestock Integration is stimulated as a way of increasing the generation of foreign exchange for Brazil. Integrated systems improve land use efficiency as well as preserve, recover and increment or soil fertility. The aim of this research was to evaluate how different doses of nitrogen fertilization can affect production and quality of dual purpose wheat submitted to grazing. The experimental designed was randomized block with five treatments $\left(0,75,150,225\right.$ and $300 \mathrm{Kg} \mathrm{N} \mathrm{ha}^{-1}$, like ammonium nitrate) and four repetitions. The forage yield, the percentage crude protein $(\mathrm{P}=.0001)$ and acid detergent insoluble protein $(\mathrm{P}=.0054)$ had a linear increased because of the nitrogen addition doses. The crude protein percentage changed the estimate of all soluble carbohydrates $(\mathrm{P}=.0001)$ and non-fibrous carbohydrates $(\mathrm{P}=.0186)$, but did not influence the, nitrogen detergent fiber corrected with ash and proteins percentage contributing for content cell. The crops production $(\mathrm{P}=.0001)$ and the number of kernels per ear $(\mathrm{P}=.0001)$ showed significantly difference because of the nitrogen additions dose, increasing the number of fertile flowers. The nitrogen topdressing alters forage production, the chemical composition and the production of dual purpose wheat grains subjected to grazing.
\end{abstract}

Key words: Meat. Fertility. Grain. Crop livestock integration. Milk. Pasture.

\section{Resumo}

Atualmente, é estimulada a prática de Integração Lavoura-Pecuária (ILP) como forma de incrementar a geração de divisas para o Brasil. Os sistemas integrados melhoram a eficiência de uso da terra, bem como preservam, recuperam e/ou incrementam a fertilidade do solo. Objetivou-se avaliar a produção e a composição bromatológica de trigo duplo propósito (TDP) manejado sob pastejo com diferentes doses de nitrogênio em cobertura (DAN): $0,75,150,225$ e $300 \mathrm{Kg}_{\mathrm{de} \mathrm{N} \mathrm{ha}}{ }^{-1}$, sob a forma de nitrato

${ }^{1}$ Discente do Curso de Mestrado do Programa de Pós-Graduação em Ciência Animal, Universidade Estadual de Londrina, UEL, Londrina PR, Brasil. E-mail: ederhenz@gmail.com

2 Profs. Adjuntos, Dept ${ }^{\mathrm{o}}$ de Zootecnia e Ciências Biológicas, Campus Palmeira das Missões, Universidade Federal de Santa Maria, UFSM, Palmeira das Missões, RS, Brasil. E-mail: pauloalmeida@smail.ufsm.br; velhojp@ufsm.br

${ }^{3}$ Prof. Associado, Dept ${ }^{\circ}$ de Tecnologia e Ciência dos Alimentos, Campus Santa Maria, UFSM, Santa Maria, RS, Brasil. E-mail: jlnornberg@gmail.com

${ }^{4}$ Prof. Dr. Associado, Dept ${ }^{\mathrm{o}}$ de Zootecnia, UEL, Londrina, PR, Brasil. E-mail: leandro@uel.br

5 Discente do Curso de Mestrado do Programa de Pós-Graduação em Zootecnia, Universidade Estadual de Maringá, UEM, Maringá PR, Brasil. E-mail: tati.gauchinha@zootecnista.com.br

${ }^{6}$ Discente do Curso de Doutorado do Programa de Pós-Graduação em Ciência Animal, UEL, Londrina PR, Brasil. E-mail: geisi_ guerra@hotmail.com

* Author for correspondence 
de amônia. Utilizou-se delineamento experimental de blocos casualizados com quatro repetições. A produção de forragem e os teores de proteína bruta $(\mathrm{P}=0,001)$ e proteína insolúvel em detergente ácido aumentaram $(\mathrm{P}=0,0054)$ linearmente, em função das DAN. O teor de proteína bruta $(\mathrm{P}=0,0001)$ impactou sobre as estimativas de carboidratos totais e de carboidratos não fibrosos, mas não influenciou $(\mathrm{P}=0,0186)$ os teores de fibra em detergente neutro corrigidas para cinzas e proteínas contribuindo para manutenção dos teores de conteúdo celular. A produção de grãos $\mathrm{P}=(0,0001)$ e o número de grãos por espigas diferiram $(\mathrm{P}=0,0001)$, em função das $\mathrm{DAN}$, aumentando o número de flores férteis. A adubação nitrogenada em cobertura altera a produção de forragem, a composição bromatológica e a produção de grãos de trigo duplo propósito submetido à pastejo.

Palavras-chave: Carne. Fertilidade. Grão. Integração Lavoura-Pecuária. Leite. Pastagem.

\section{Introduction}

Currently, it is stimulated the practice of CropLivestock Integration (CLI) as a way of increasing the generating of foreign exchange for Brazil. The integrated systems improve land use efficiency, as well as preserve, recover and / or increment the fertility of the soil. One way to increase the recycling of nutrients is the insertion of annual pastures used under grazing, which can be developed for this reason such as double-purpose wheat (Triticum aestivum) (DPW), which besides providing gain (meat and or milk) per animal per area also produces grain, which may even be bread making.

The use of the DPW for grazing permits early cultivation minimizing and / or nullifying the effects of empty autumnal forage. However, the entry of animals in the system generates dynamic interactions in soil-plant-animal relationship, which products are still poorly understood by most technicians. So researches on CLI are essential.

The fertilizer recommendations for wheat production in the southern region are based exclusively for grains. However, the DPW cultivation is differentiated, as it before reaching the peak of its production (grains) it is subjected to defoliation of different intensities (pasture supply, animal stocking and animal category) and frequencies (system and grazing number) but regardless of the degree it is a stress for dual purpose plant by which cultivars that produce only wheat do not pass. Thus, it is conjectured that the DPW under grazing should receive higher doses of nitrogen fertilization, in order to stimulate the regrowth and not decrease grain production.

The nitrogen $(\mathrm{N})$ is possibly the second most limiting of agricultural production, losing only to water deficiency (GRAHAM; VANCE, 2000). Generally, studies on level of nitrogen fertilization (LNF) approach grain production, but the dual purpose wheat requires information not only at the beginning of the reproductive stage, but also the production of biomass and chemical composition of it during the vegetative stage. So, the objective was to evaluate the production and chemical composition of dual-purpose wheat pasture managed with different LNF coverage aiming crop production (pasture and grain) and animal (milk and/or beef).

\section{Material and Methods}

The study was conducted at Librelotto Farm in Boa Vista das Missões - RS. The soil is classified as Rhodic Hapludox, $600 \mathrm{~g} \mathrm{~kg}^{-1}$ of clay level, deep and well drained. At the beginning of the experiment we found that the soil contained: $\mathrm{pH}\left(\mathrm{H}_{2} \mathrm{O}\right)=5,6 ; \mathrm{P}=$ $7,1 \mathrm{mg} \mathrm{dm} 3 ; \mathrm{K}=121 \mathrm{mg} \mathrm{dm}{ }^{3} ; \mathrm{M} . \mathrm{O}=3,5 \% ; \mathrm{Al}=0,0$ $\mathrm{cmol} \mathrm{dm}^{3} ; \mathrm{Ca}=5,9 \mathrm{cmol} \mathrm{dm}^{3} ; \mathrm{Mg}=3,2 \mathrm{cmol} \mathrm{dm}^{3}$; $\mathrm{CTC}=13,8 \mathrm{cmol} \mathrm{dm}^{3}$; SAT bases $=68 \%$.

It was used a randomized experimental blocks with five treatments $(0,75,150,225$ and $300 \mathrm{Kg}$ of $\mathrm{N} \mathrm{ha}^{-1}$, in the form of ammonium nitrate) and four replications. Each plot was composed of 
(9x4m) totaling $36 \mathrm{~m} 2$. The wheat cultivation BRS Tarumã ${ }^{\circledR}$ was preceded by two grasses: the normal time corn for grain production and then pearl millet (Pennisetum americanum) which was used for grazing. All cultures were performed at Librelotto Farm, and they were performed according to the premises of no tillage system. Sowing was performed using ( $140 \mathrm{Kg}$ of viable seeds ha-1) in the second fortnight of April 2012. Basic fertilization was performed with use of $300 \mathrm{~kg} \mathrm{ha}^{-1}$ of the formulated 10-20-10 $\left(\mathrm{N}-\mathrm{P}_{2} \mathrm{O}_{5}-\mathrm{K}_{2} \mathrm{O}\right)$. The first LFN coverage was applied 27 days after sowing (DAS) to stimulate the tiller stage and the growth of the plants, the second LFN occurred 70 (DAS = day after the first grazing) and the third LFN at the 87 (DAS = day after the second grazing). Both of those pasturing occurred during eight hours (7:30 - 15: 30h) using 25 Holstein cows owned by Busanello Farm with average live weight of $650 \mathrm{~kg}$ so that the instantaneous stocking rate was $225,000 \mathrm{~kg}$ live weight per hectare.

The measurement of available biomass per hectare was performed one day before the pasturing and soon after them, residues were determined using a squared of $0,25 \mathrm{~m}^{2}$, by cutting the plants at ground level, then they were weighed to obtain the green matter. Posteriorly, they were pre-dried in a forced air circulation oven for 72 hours at $55^{\circ} \mathrm{C}$.

It was evaluated: dry matter production (DMP), accumulation rate daily (ARD), estimate consumption, residue after grazing, nitrogen use efficiency (NUE) in the plant according to the procedures described by Lupatini et al. (1998), grain production (GP), hectoliter weight (HW), length of cobs (LC), number of grains per cob (NGC) and percentage of layering (PL). The residual straw was assessed on the day of harvest of the grains.

After the determination of the partially dry matter content, was held the grinding in a Wiley mill with sieve of one millimeter. It was determined the contents of dry matter (DM), mineral matter $(\mathrm{MM})$, ether extract (EE), crude protein $(\mathrm{CP})$, neutral detergent insoluble protein (NDIP) and acid (ADIP), neutral detergent fiber corrected for ashes and protein (NDFap) and acid (ADFap), lignin (LIG), cellulose (CEL) and hemicelluloses (HEM) according to the procedures described by Silva and Queiroz (2002). Subsequently, it was estimated the total carbohydrates content CHOT $(\% \mathrm{DM})=100$ $[\mathrm{CP}(\% \mathrm{DM})+\mathrm{EE}(\% \mathrm{DM})+\mathrm{MM}(\% \mathrm{MM})]$, nonfiber carbohydrates NFC $(\% \mathrm{DM})=\mathrm{CHOT}(\% \mathrm{DM})$ NDIP (\%DM) according to Sniffen et al. (1992) and the total digestible nutrients (TDN) by the formula of Weiss et al. (1992).

Two fungicide applications were performed, $250 \mathrm{~mL} \mathrm{ha}^{-1}$ of Azoxystrobin and $250 \mathrm{~mL} \mathrm{ha}^{-1}$ of Ciproconazole per application, being the first dose at 117 DAS and the second dose at 142 DAS. The grain harvesting occurred at 218 DAS. The results were submitted to regression analysis, it was used the software SAS version 8.2 (SAS, 2001).

\section{Results and Discussion}

The DMP in the first and second grazing increased linearly $(\mathrm{P}<0.01)$, depending on the LNF (Figure 1 and 2). Evaluating increasing levels of nitrogen until $120 \mathrm{Kg} \mathrm{N}^{-1}$ Hastenpflug et al. (2011) have obtained linear growth in forage production up to the maximum dose. Therefore, we conjecture that the LNF currently recommended limit forage potential of the DPW. The DMP between the first and second grazing was almost double in all treatments, in relation to the amount of forage for the first grazing. This result makes clear that despite the defoliation be a stress factor for the plant (1st grazing) it stimulates regrowth, as well as the growth of root biomass, so that the grazing provides greater production of organic matter per hectare, by capturing more carbon into the system. 
Figure 1. Production first cut dry matter $\left(\mathrm{kg} \mathrm{ha}^{-1}\right)$ and residue from the first cut $\left(\mathrm{Kg} \mathrm{ha}^{-1}\right)$ as a function of nitrogen in coverage.

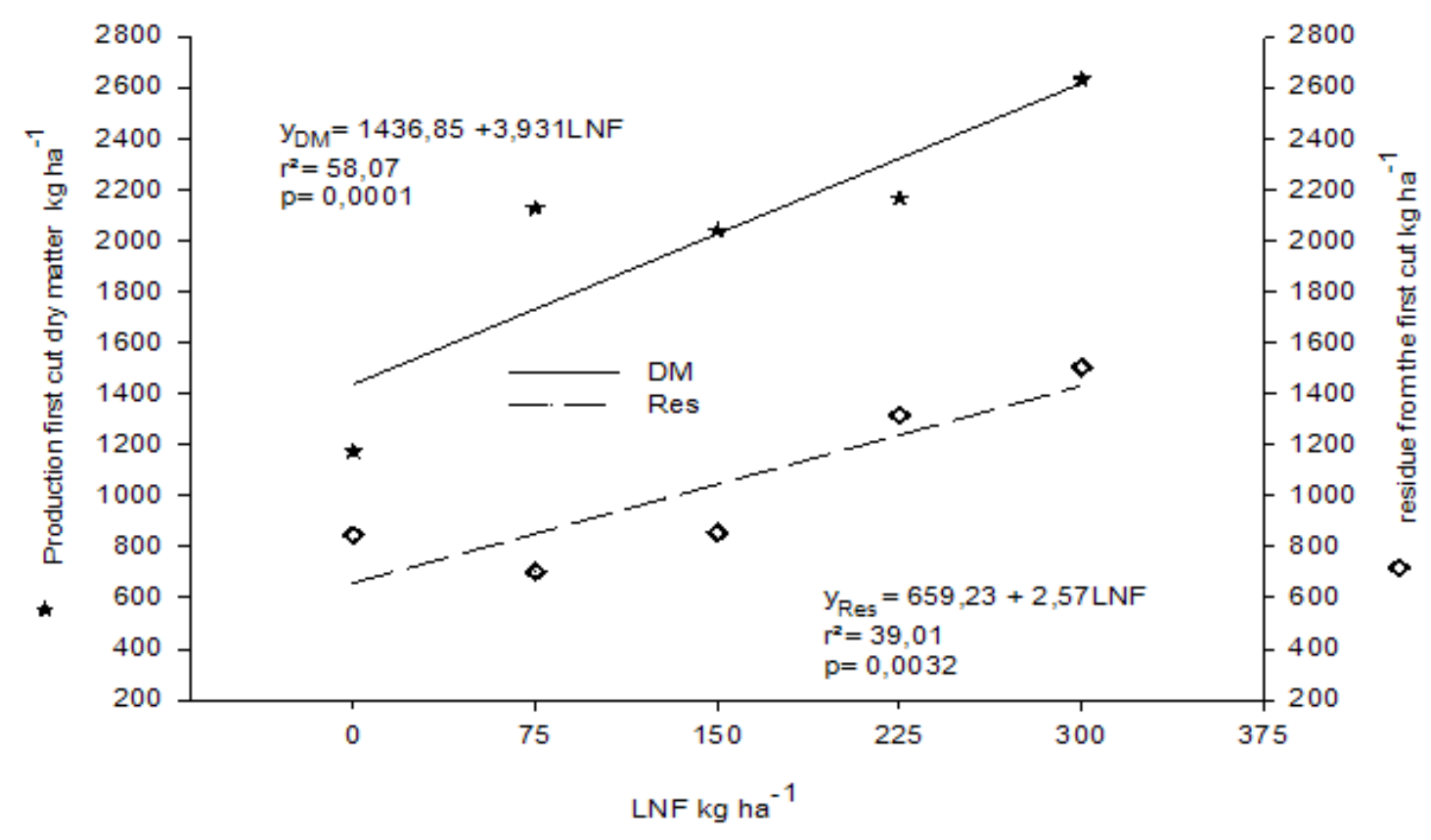

Figure 2. Production second cut dry matter $\left(\mathrm{kg} \mathrm{ha}^{-1}\right)$ and the second cut residue $\left(\mathrm{Kg} \mathrm{ha}^{-1}\right)$ as a function of nitrogen in coverage.

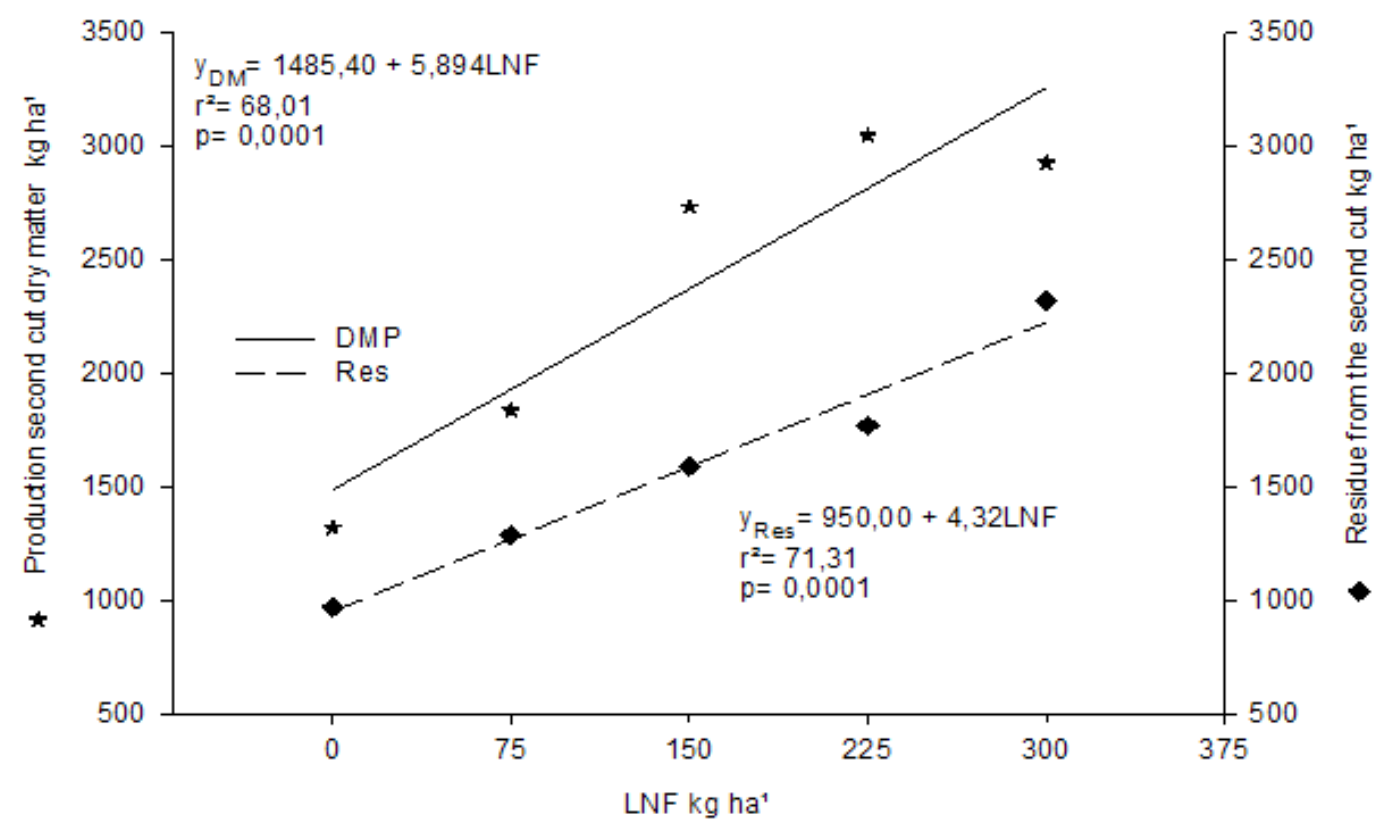

Each winter cereal culture dual purpose management performed according to the available responds differently, after defoliation, as the yield biomass and maintenance of residue (Figure 1 of matter, the ability of regrowth and the emission and 2) along with the nitrogen cover fertilization of new tillers (BORTOLINI et al., 2004). Pasture applied in divided doses stimulate regrowth, which 
can be measured by the daily accumulation rate (DAR) that showed (Figure 3) quadratic behavior $(\mathrm{P}=0.0003)$, so that the most suitable LNF would be at the $150 \mathrm{~kg}$ whereas above it stimulates senescence and, thus reduce bioeconomic efficiency.

Figure 3. Accumulation rate daily $\left(\mathrm{kg} \mathrm{ha}^{-1}\right)$ and nitrogen use efficiency $\left(\mathrm{kg} \mathrm{ha}^{-1}\right)$ as a function of nitrogen in coverage.

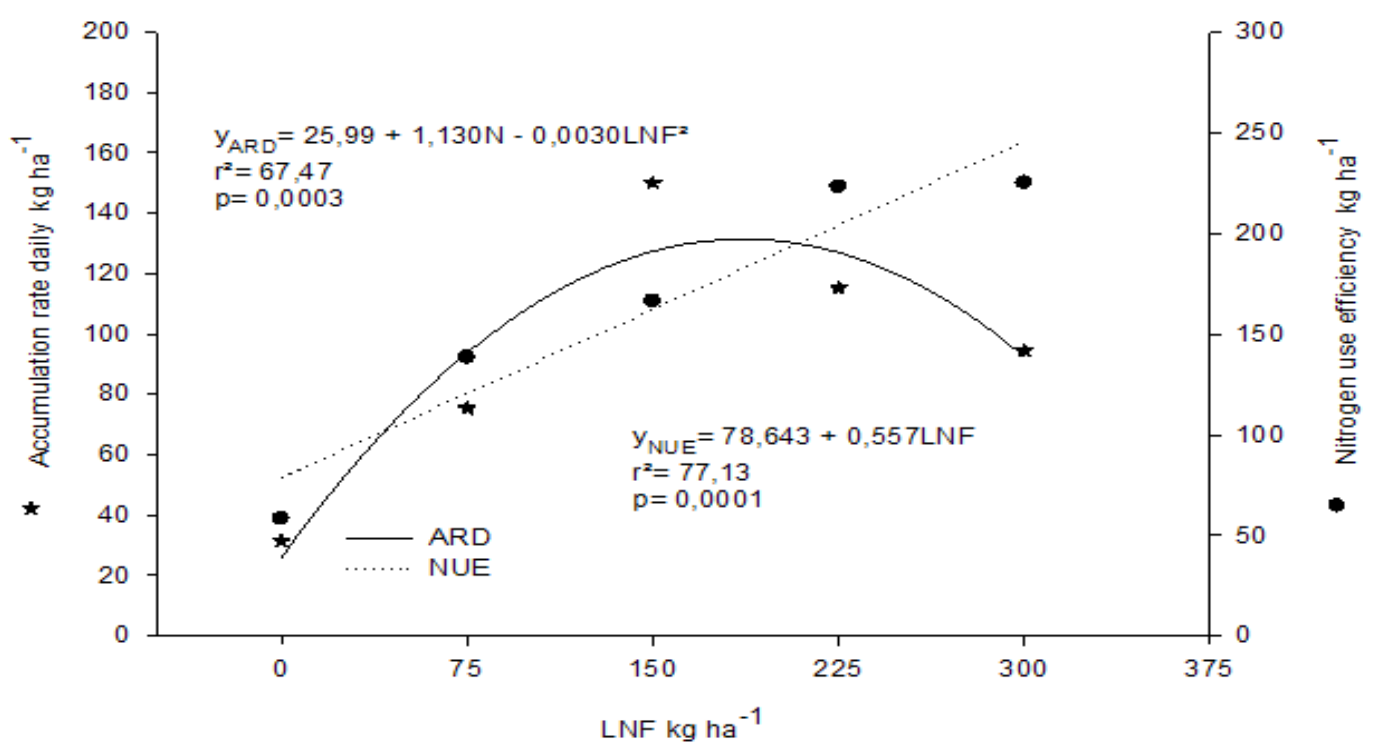

Generally, grass pastures have longer growth periods than other forage genres, and are more responsive to nitrogen fertilization (ASSMANN et al., 2004). Successive grazing in the same area with rotational grazing are mainly defined by the management of leaf area index (WILKINS et al., 2000). It can be seen (Figure 1) that the larger the LNF shorter time for a new pasture. It is conjectured that larger LNF allows more grazing during the vegetative stage. However, in CLI system a decision to more or less grazing in dual purpose crops such as DPW it cannot be in an isolated manner, since it can compromise the bio economic efficiency of production of the second product (grain), and any subsequent cultures. We indicate consider the condition of the rural company the total index, ie, agronomic and animal science indexes, as well as the marketing situation of the production chains involved in the CLI system at least for the next agricultural year.
The residual pasture after the first and second grazing were linearly influenced $(\mathrm{P}<0.01)$, according to increased LNF the residue was incremented, because the cattle seek to choose the most nutritious parts of the forage plant which are the green leaf blades. The pasture intake estimated by the group of animals was on average of $14.13 \mathrm{~kg} \mathrm{DM}$, which is equivalent to approximately $2.17 \%$ of the live weight of the cows used to produce on average $30 \mathrm{~kg}$ of milk per cow per day. Pasture intake is directly related to the mass bite, the bite rate and grazing time, which are non-nutritional factors that affect the voluntary intake of dry matter, structural characteristics of grasslands and behavioral factors of animals (CARVALHO et al., 2011).

The NUE (Figure 3) by the DPW plants occurred in a linear manner $(\mathrm{P}=0.0001)$ demonstrating that it has not reached the maximum rate of nutrient absorption yet. Probably, the supply of higher LNF should have occurred in a more fractionated 
manner, since it would increase even more DMP, since it has not reached the maximum point, and therefore would increase the load and the animal performance per hectare. Despite the decrease in the NUE the average was $83 \%$. Studying the recovery of nitrogen in ryegrass pastures and triticale Soares and Restle (2002) obtained average values of only $37 \%$. Such differences between the works may have occurred by genetic differences among the cultures studied.

The DM and CP contents were altered linearly $(\mathrm{P}<0.01)$ by LNF. However, inversely, i.e. DM decreased and CP increased (Table 1). The more N in vegetative stage greater is the presence of water in plants. In evaluating the chemical composition of four cultivars of DPW Hastenpflug et al. (2011), observed linear increase $(P<0.05)$ in the $\mathrm{CP}$ content to the maximum dose of $120 \mathrm{Kg}$ of $\mathrm{N}$ $\mathrm{ha}^{-1}$. Both studies showed that the DPW presents plasticity in relation to nitrogen absortion. The NDIP was not changed $(\mathrm{P}>0.05)$ by treatments. In spite of the protein fraction unavailable to rumen microorganisms and the host ADIP have increased $(\mathrm{P}=0.0054)$ linearly according to the LNF it can be disregarded, once it regardless of the treatment there will be enough nitrogen to the physiological rumen metabolism.

Table 1. Average levels and regression of wheat pasture chemical composition dual purpose managed grazing and with different level of nitrogen fertilization (LNF).

\begin{tabular}{|c|c|c|c|c|c|c|}
\hline \multirow{3}{*}{ Parameter } & \multirow{3}{*}{ Statistical } & \multirow{2}{*}{\multicolumn{5}{|c|}{ Level of nitrogen fertilization $\left(\mathbf{K g} \mathbf{~ d e ~} \mathbf{N} \mathbf{h a}^{-1}\right)$}} \\
\hline & & & & & & \\
\hline & & $\mathbf{0}$ & 75 & 150 & 225 & 300 \\
\hline \multirow{2}{*}{ Dry matter $(\% \mathrm{NM})$} & Mean & 22.34 & 19.89 & 17.85 & 15.59 & 15.39 \\
\hline & Regression & \multicolumn{5}{|c|}{$\hat{\mathrm{Y}}_{\mathrm{DM}}=21.852-0,02427 * \mathrm{LNF}\left(\mathrm{r}^{2}=78.32 ; \mathrm{P}=0.0001\right)$} \\
\hline \multirow{2}{*}{$\begin{array}{l}\text { Mineral matter } \\
\quad(\% \mathrm{DM})\end{array}$} & Mean & 9.89 & 10.26 & 11.62 & 12.57 & 11.99 \\
\hline & Regression & \multicolumn{5}{|c|}{$\hat{\mathrm{Y}}_{\mathrm{MM}}=9.96+0.0086^{*} \mathrm{LNF}\left(\mathrm{r}^{2}=60.68 ; \mathrm{P}=0.0001\right)$} \\
\hline \multirow{2}{*}{$\begin{array}{c}\text { Ethereal extract } \\
(\% \mathrm{DM})\end{array}$} & Mean & 3.63 & 3.99 & 4.05 & 3.71 & 3.71 \\
\hline & Regression & \multicolumn{5}{|c|}{$\hat{\mathrm{Y}}_{\mathrm{EE}}=3.81$} \\
\hline \multirow{2}{*}{$\begin{array}{c}\text { Total carbohydrates } \\
\text { (\% DM) }\end{array}$} & Mean & 70.30 & 64.21 & 62.36 & 59.90 & 59.01 \\
\hline & Regression & \multicolumn{5}{|c|}{$\hat{\mathrm{Y}}_{\text {СНОт }}=68.53-0.0398 * \operatorname{LNF}\left(\mathrm{r}^{2}=60.42 ; \mathrm{P}=0.0001\right)$} \\
\hline \multirow{2}{*}{$\begin{array}{c}\text { Non-fiber } \\
\text { carbohydrates } \\
(\% \mathrm{DM})\end{array}$} & Mean & 19,69 & 14,90 & 12,90 & 8,91 & 10,70 \\
\hline & Regression & \multicolumn{5}{|c|}{$\hat{\mathrm{Y}}_{\mathrm{CNF}}=16.61-0.029 * \mathrm{LNF}\left(\mathrm{r}^{2}=27.10 ; \mathrm{P}=0.0186\right)$} \\
\hline \multirow{2}{*}{$\begin{array}{l}\text { NDFap } \\
(\% \text { DM })\end{array}$} & Mean & 50.60 & 54.50 & 49.98 & 50.31 & 48.32 \\
\hline & Regression & \multicolumn{5}{|c|}{$\hat{\mathrm{Y}}_{\mathrm{NDFap}}=50.73$} \\
\hline \multirow{2}{*}{$\begin{array}{l}\text { ADFap } \\
(\% \text { DM })\end{array}$} & Mean & 24.98 & 25.84 & 26.26 & 27.08 & 26.53 \\
\hline & Regression & \multicolumn{5}{|c|}{$\hat{\mathrm{Y}}_{\mathrm{ADFap}}=25.27+0.0057 * \mathrm{LNF}\left(\mathrm{r}^{2}=27.49 ; \mathrm{P}=0.0176\right)$} \\
\hline \multirow{2}{*}{$\begin{array}{r}\text { Cellulose } \\
(\% \mathrm{DM})\end{array}$} & Mean & 19.80 & 21.19 & 21.01 & 22.42 & 21.09 \\
\hline & Regression & \multicolumn{5}{|c|}{$\hat{\mathrm{Y}}_{\mathrm{CEL}}=21.00$} \\
\hline \multirow{2}{*}{$\begin{array}{l}\text { Hemicelluloses } \\
(\% \mathrm{DM})\end{array}$} & Mean & 25.62 & 28.65 & 23.71 & 23.23 & 21.77 \\
\hline & Regression & \multicolumn{5}{|c|}{$\hat{\mathrm{Y}}_{\mathrm{HEM}}=24.54$} \\
\hline \multirow{2}{*}{$\begin{array}{l}\text { Lignin } \\
(\% \mathrm{DM})\end{array}$} & Mean & 5.18 & 4.65 & 5.25 & 4.66 & 5.44 \\
\hline & Regression & \multicolumn{5}{|c|}{$\hat{\mathrm{Y}}_{\mathrm{LIG}}=5.03$} \\
\hline \multirow{2}{*}{$\begin{array}{l}\text { Crude protein } \\
\quad(\% \mathrm{DM})\end{array}$} & Mean & 16.16 & 21.53 & 21.95 & 26.79 & 25.28 \\
\hline & Regression & \multicolumn{5}{|c|}{$\hat{\mathrm{Y}}_{\mathrm{CP}}=16.64+0.031 * \mathrm{LNF}\left(\mathrm{r}^{2}=58.16 ; \mathrm{P}=0.0001\right)$} \\
\hline
\end{tabular}


Continuation

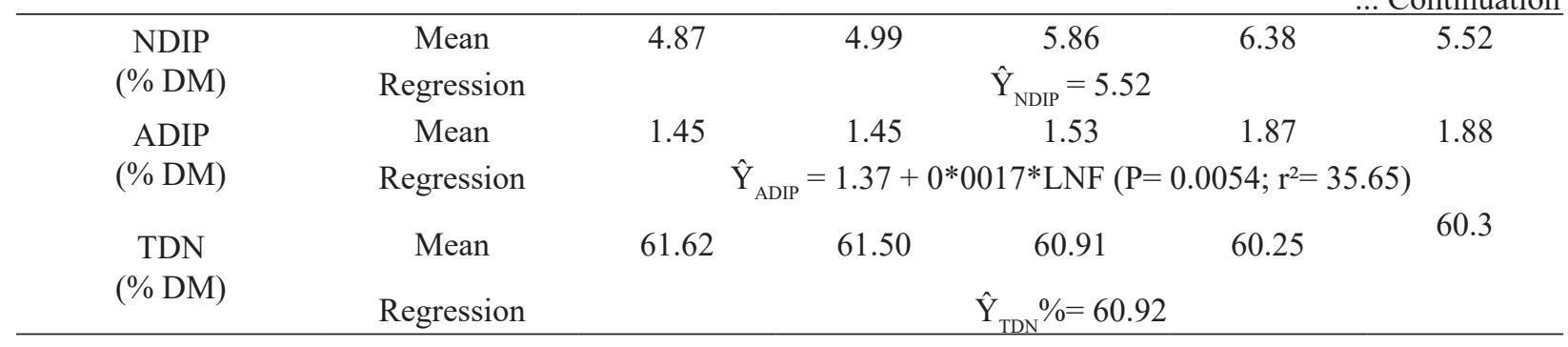

Natural matter (NM), dry matter (DM), mineral matter (MM), ethereal extract (EE), crude protein (CP), neutral detergent insoluble protein (NDIP) and acid (ADIP), neutral detergent fiber corrected for ashes and protein (NDFap) and acid (ADFap), lignin (LGI), cellulose (CEL) and hemicelluloses (HEM), total digestible nutrients (TDN).

The LNF have increased the MM contents $(\mathrm{P}=0.0001)$. Probably, this result is due to the interaction of nutrients in the soil, influenced by the amount of organic matter in soil, originated from continued use of agricultural corrective and fertilizers, but mainly by direct planting system in straw planned and executed with crop rotation, using on average three crops a year and integrated into cattle raising activity. In future work it is recommended to distinguish the composition of MM, because these may impact on the mineral nutrition of ruminants.

The contents of EE, NDFap, CEL, HEM, and LGI (Table 1) did not change ( $\mathrm{P}>0.05)$ of the LNF. The addition of $\mathrm{CP}$ interfered in the estimates of CHOT $(\mathrm{P}=0.0001)$ and NFC $(\mathrm{P}=0.0186)$, but did not influence the NDFap content. The addition of $\mathrm{CP}$ interfered with estimates of CHOT $(\mathrm{P}=0.0001)$ and NFC $(\mathrm{P}=0.0186)$ but did not influence the NDFap content. Therefore, there was maintenance of cellular content levels, but with variation in the composition of it, since it increased the $\mathrm{CP}$ and linearly decreased the NFC, which together with the maintenance of NDFap levels it is of fundamental importance for animal production, since it encourages the voluntary consumption, as well as ruminal microbial growth, mitigating enteric production of greenhouse gases.

Despite the increase in ADFap, regarding the LNF, this effect was not sufficient to reduce the TDN estimates $(\hat{Y}=60.92)$ corroborating to demonstrate the high energy of all digestible plant components showing the vocation of the forage for animal feed, probably resulting in an increased voluntary consumption and therefore in animal production.

The GP, NGC and LC increased $(\mathrm{P}<0.01)$ linearly (Figure 4). Increasing nitrogen levels have enabled lengthening cob providing more fertile flowers and consequently raising grain yield. Studying DPW cultivars in Brazil Del Duca et al. (2001) they found that genotypes subjected to cutting showed higher productivity of grain than those uncut. 
Figure 4. Grain production $\left(\mathrm{kg} \mathrm{ha}^{-1}\right)$, number of grains per $\mathrm{cob}\left(\mathrm{kg} \mathrm{ha}^{-1}\right)$ and length of cobs $\left(\mathrm{cm} \mathrm{ha}^{-1}\right)$ as a function of nitrogen in coverage.

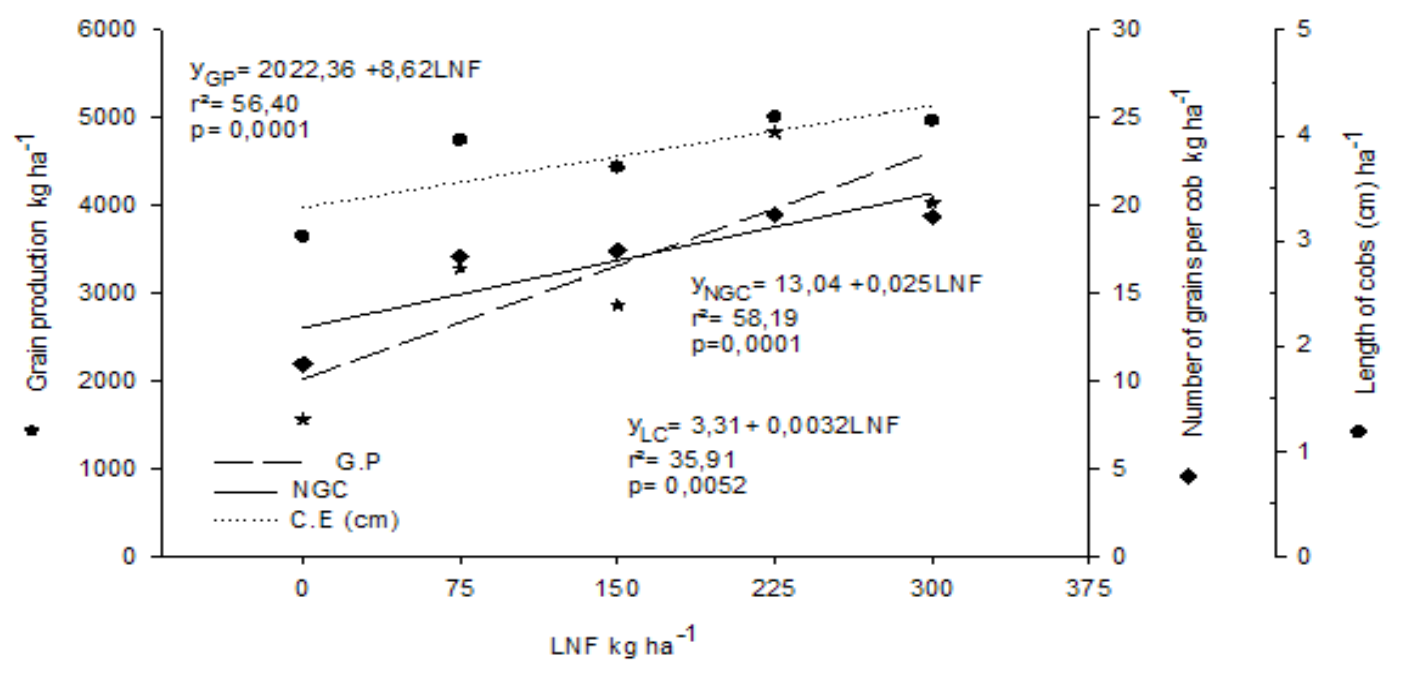

Genetic improvement measured by the increase of wheat yield potential it is due to the significant share of the number of grains per spike (RODRIGUES, 2000). Working with DPW (BRS Tarumã $\left.{ }^{\circledR}\right)$ Hastenpflug et al. (2011) obtained a reduction in grain production and number of spikes per spikelet as increased the number of cutting (two) which was not identified in this study with two grazing with high load instantaneous animal.

The HW variables $(\hat{Y}=73.26)$ and thousand seed weight $(\hat{Y}=25.98)$ did not differ $(\mathrm{P}>0.05)$ between treatments. The determination of HW lets you sort the wheat grains into three categories, according to rules published by the Ministry of Agriculture (BRASIL, 2001): type 1, the HW is 78 , Type 2 , the HW is 75 , and Type 3 , the HW is 70 . The edaphoclimatic factors (rain and wind) that occurred during the 15 days prior to harvesting influenced the GP.
The layering of DPW plants are explained $67.81 \%$ by LNF (Figure 5) which is compatible with the linear response of EC and NGC, which resulted in increase in GP per hectare. Therefore, to decide which LNF should be used in the DPW, beyond the parameters evaluated in this study should consider the risks of bad weather in the final stage of the crop, because of $32.19 \%$ of random effects, probably the inclement weather are those that most determine the production and quality of harvested DPW.

In a study performed by Espindula et al. (2010) with the Pioneer wheat cultivar, they found susceptibility to layering due to the fractioning of $\mathrm{N}$ rates, can be explained by excessive vegetative growth causing nutritional imbalance, low culm resistance, mass of spikes and unfavorable climatic factors among others. In the production of residue remaining from the wheat crop it was observed that, there was a linear increase $(\mathrm{P}=0.0001)$ due to the increase of LNF reaching over $9 \times 10^{-3} \mathrm{Kg}$ MS $\mathrm{ha}^{-1}$. 
Figure 5. Percentage of layering $\left(\% \mathrm{ha}^{-1}\right)$ and the remaining crop residue $\left(\mathrm{kg} \mathrm{ha}^{-1}\right)$ as a function of nitrogen in coverage.

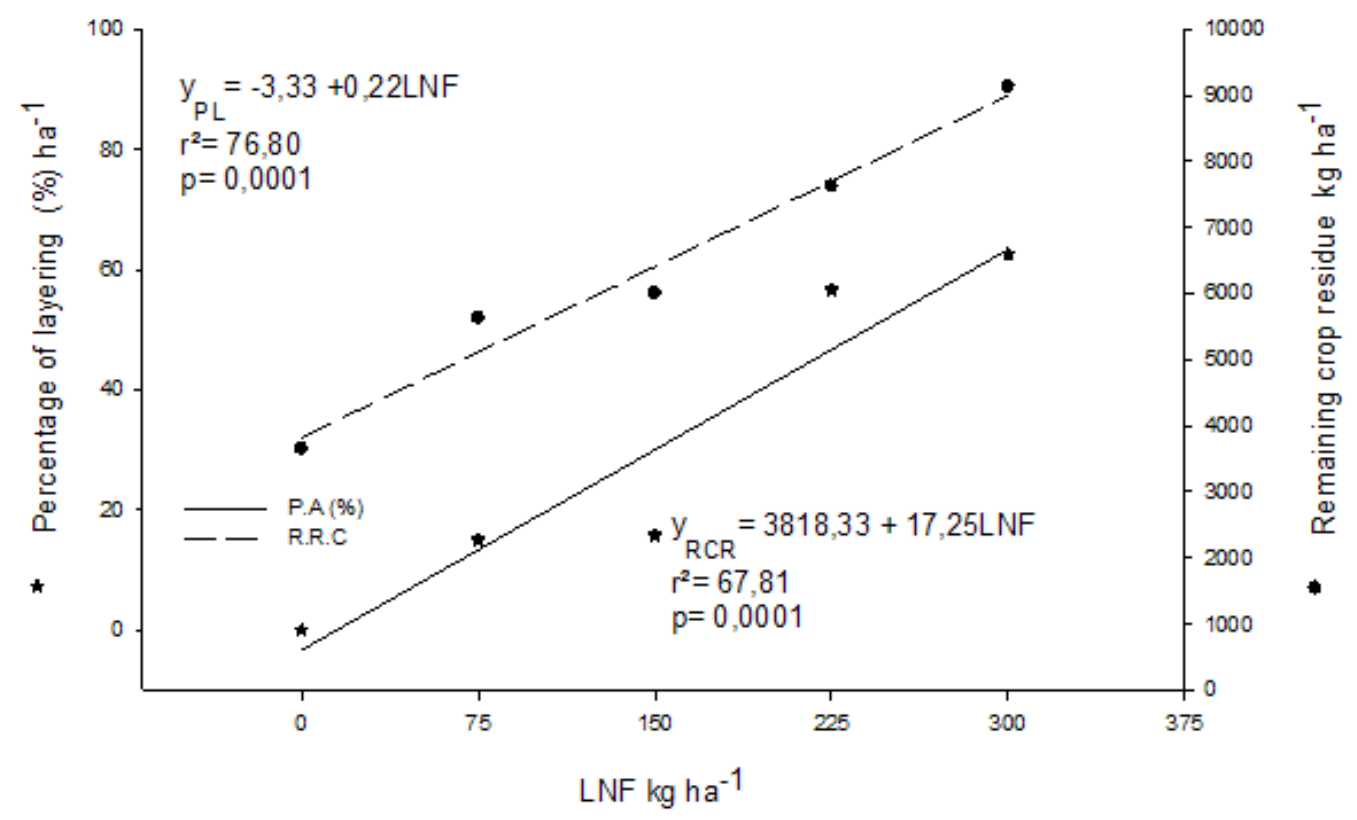

\section{Conclusion}

The nitrogen fertilization changes positively and linearly the production of forage and wheat grain dual purpose subjected to grazing. The chemical composition stands out for its high concentration of dry matter, mineral matter, crude protein, nonfibrous carbohydrates and fiber, showing the high potential of forage dual purpose wheat BRS Tarumã ${ }^{\circledR}$, when subjected to increasing doses of nitrogen fertilization and subjected to grazing.

\section{Acknowledgements}

The authors thank Librelotto Farm, especially Mr. Ivonei Sandro Librelotto and Bussanello Family, for stimulating the research and not measuring efforts for the execution of the activities.

\section{References}

ASSMANN, A. L.; PELISSARI, A.; MORAES, A. de; ASSMANN, T. S.; OLIVEIRA, E. B. de; SANDINI, I. Produção de gado de corte e acúmulo de matéria seca em sistema de integração lavoura-pecuária em presença e ausência de trevo branco e nitrogênio. Revista Brasileira de Zootecnia, Viçosa, MG, v. 33, n. 1, p. 37-44, 2004.

BORTOLINI, P. C.; SANDINI, I.; CARVALHO, P. C. F.; MORAES, A. de. Cereais de inverno submetidos ao corte no sistema de duplo propósito. Revista Brasileira de Zootecnia, Viçosa, MG, v. 33, n. 1, p. 45-50, 2004.

BRASIL. Ministério da Agricultura, Pecuária e Abastecimento. Instrução normativa ${ }^{\circ}$ 7, de 15/08/2001. Regulamento técnico de identidade e qualidade do trigo. Diário Oficial [da] União, Brasília, 21 out. 2001 Seção 1. p. 33-35.

CARVALHO, P. C. F.; RIBEIRO FILHO, H. M. N.; POLI, C. H. E. C.; MORAES, A.; DELAGARDE, R. Importância da estrutura da pastagem na ingestão e seleção de dietas pelo animal em pastejo. In: REUNIÃO ANUAL DA SOCIEDADE BRASILEIRA DE ZOOTECNIA, FEALQ, 2011, Piracicaba. Anais... Piracicaba: FEALQ, 2011. p. 853-871.

DEL DUCA, L. de J. A.; MOLIN, R.; ANTONIAZZI, N. Resultados da experimentação de genótipos de trigo para aptidão a duplo propósito no Paraná, em 2000. Passo Fundo: Embrapa Trigo, 2001. 44 p. (Embrapa Trigo. Boletim de pesquisa e desenvolvimento, 6).

ESPINDULA, M. C.; ROCHA, V. S.; SOUZA, M. A. de; SOUZA, L. T. de. Doses e formas de aplicação de nitrogênio no desenvolvimento e produção da cultura de trigo. Ciência e Agrotecnologica, Lavras, v. 34, n. 6, p. 1404-1411, 2010. 
GRAHAM, P. H.; VANCE, C. P. Nitrogen fixation in perspective: an overview of research and extension needs. Field Crops Research, Amsterdam, v. 65, n. 2-3, p. 93-106, 2000.

HASTENPFLUG, M.; BRAIDA, J.; MARTIN, T.; ZIECH, M.; SIMIONATTO, C.; CASTAGNINO, D. Cultivares de trigo duplo propósito submetidos ao manejo nitrogenado e a regimes de corte. Arquivo Brasileiro de Medicina Veterinária e Zootecnia, Belo Horizonte, v. 63, n. 1, p. 196-202, 2011.

LUPATINI, G. C.; RESTlE, J.; CERETTA, M.; LONDERO, E.; RENE, H. Avaliação da mistura de aveia preta e azevém sob pastejo submetida a níveis de nitrogênio. I - Produção e qualidade de forragem. Pesquisa Agropecuária Brasileira, Brasília, v. 33, n. 11, p. 1939-1943, 1998.

RODRIGUES, O. Manejo de trigo: bases ecofisiológicas. In: CUNHA, G. R.; BACALTCHUK, B. (Org.). Tecnologia para produzir trigo no Rio Grande do Sul. Porto Alegre: Assembleia Legislativa. Comissão de Agricultura Pecuária e Cooperativismo. Passo Fundo: Embrapa Trigo, 2000. 404 p. (Série Culturas, n. 02).

SILVA, D. J.; QUEIROZ, A. C. Análise de alimentos: métodos químicos e biológicos. 3. ed. Viçosa, MG: Universidade Federal de Viçosa, 2002. 235 p.
SNIFFEN, C.J.; O'CONNOR, J. D.; VAN SOEST, P. J.; FOX, D. G.; RUSSELL, J. B. A net carbohydrate and protein system for evaluating cattle diets: II. Carbohydrate and protein availability. Journal of Animal Science, Champaign, v.70, n. 12, p. 3562-3577, 1992.

SOARES, A. B.; RESTLE, J. Adubação nitrogenada em pastagem de triticale mais azevém sob pastejo com lotação contínua: recuperação de nitrogênio e eficiência na produção de forragem. Revista Brasileira de Zootecnia, Viçosa, MG, v. 31, n. 1, p. 43-51, 2002.

STATISTICAL ANALYSIS SYSTEM - SAS. Statistical analysis system user's guide: statistics. Cary: SAS Institute, 2001.

WEISS, W. P.; CONRAD, H. R.; ST. PIERRE, N. R. A theoretically-based model forpredicting total digestible nutrient values of forages and concentrates. Animal Feed Science and Technology, Amsterdam, v.39, p.95-110, 1992.

WILKINS, P. W.; ALLEN, D. K.; MYTTON, L. R. Differences in the nitrogen use efficiency of perennial ryegrass varieties under simulated rotational grazing and their effects on nitrogen recovery and herbage nitrogen content. Grass and Forage Science, Oxford, v. 55, n. 1, p. 69-76, 2000. 